\title{
Simulasi dan Analisis Stabilitas Transien dan Pelepasan Beban pada Sistem Kelistrikan PT. Semen Indonesia Pabrik Aceh
}

\author{
David Firdaus, Ontoseno Penangsang, dan Ni Ketut Aryani \\ Jurusan Teknik Elektro, Fakultas Teknologi Industri, Institut Teknologi Sepuluh Nopember (ITS) \\ Jl. Arief Rahman Hakim, Surabaya 60111 Indonesia \\ e-mail: aing.davidfirdaus@gmail.com,zenno_379@yahoo.com,ketut.aryani@gmail.com
}

\begin{abstract}
Abstrak-PT. Semen Indonesia adalah perusahaan BUMN penghasil semen terbesar dimana akan melakukan perencanaan pembangunan pabrik Semen Aceh. Dalam perencanaannya, sistem kelistrikan pada pabrik Semen Aceh akan menggunakan dua sumber yakni PLN pada sistem kelistrikan alternatif 1 dan Generator $30 \mathrm{MW}$ dan Generator 2x25 MW pada sistem kelistrikan alternatif 2 sehingga perlu dilakukan studi stabilitas transien untuk mengetahui kestabilan sistem saat terjadi gangguan transien. Pada tugas akhir ini difokuskan pada analisis kestabilan transien meliputi kestabilan tegangan, kestabilan frekuensi dan kestabilan sudut rotor saat terjadi generator outage, motor starting dan gangguan hubung singkat. Dari hasil simulasi sistem kelistrikan alternatif 2 , menunjukkan bahwa pada kasus lepasnya generator mengakibatkan frekuensi sistem tidak stabil. Untuk mengembalikan kestabilan sistem, pada kasus lepasnya generator (841BG02) memerlukan pelepasan beban 2 tahap dengan melepas $25.02 \%$ dari total beban $(9,97 \mathrm{MW})$. Saat kasus hubung singkat pada level tegangan $0,4 \mathrm{kV}$ tidak terlalu berpengaruh pada kestabilan meskipun mengakibatkan tegangan turun sesaat dan dapat kembali pada keadaan semula. Selain itu pada kasus hubung singkat dilevel tegangan $6,3 \mathrm{kV}$, setiap nilai level tegangan akan turun setelah terjadi gangguan hubung singkat 3 fasa pada level tegangan 6,3 kV, namun setelah CB5-831MV081 open maka nilai tegangan sesaat menjadi $108,359 \%$ dan akan kembali steady state pada 97,09\%. Pada kasus motor starting, penurunan tegangan terendah sempat mencapai titik terendah pada $65,79 \%$ dan stabil pada $91,456 \%$.
\end{abstract}

Kata Kunci-kestabilan transien, gangguan transien, pelepasan beban.

\section{PENDAhULUAN}

$\mathrm{S}$ uatu sistem dikatakan stabil ketika terdapat keseimbangan antara daya mekanik pada penggerak utama generator dengan daya output listrik. Dalam keadaan setimbang maka generator berputar pada kecepatan sinktron. Daya output listrik sangat dipengaruhi oleh fluktuasi beban dimana ketika terjadi kenaikan atau penurunan beban maka harus diikuti oleh perubahan daya mekanik yang dihasilkan oleh prime mover. Apabila prime mover tidak mampu menyesuaikan dengan kondisi beban akan mengakibatkan kondisi sistem menjadi tidak stabil.

Stabilitas transien berhubungan dengan gangguan besar secara tiba-tiba seperti gangguan hubung singkat, pemutusan saluran secara tiba-tiba melalui Circuit Breaker (CB), serta pemindahan beban secara tiba-tiba. Apabila gangguan besar terjadi dan tidak segera dihilangkan, maka percepatan atau perlambatan sudut rotor akan terjadi dan dapat mengakibatkan generator lossing synchronism.

Gangguan transien sangat mempengaruhi stabilitas dari suatu sistem kelistrikan pada industri-industri besar seperti PT. Semen Indonesia Aceh sehingga pada sistem kelistrikan PT. Semen Indonesia Aceh perlu dilakukan studi analisis stabilitas transien untuk mengetahui kestabilan sistem saat terjadi gangguan transien. Pada tugas akhir ini difokuskan pada analisis kestabilan transien meliputi kestabilan tegangan dan kestabilan frekuensi untuk sistem kelistrikan alternatif 1 dan kestabilan tegangan, frekuensi serta kestabilan sudut rotor untuk sistem kelistrikan alternatif 2 saat terjadi generator outage, motor starting dan gangguan hubung singkat serta analisis mekanisme pelepasan beban yang handal untuk mengatasi gangguan jika diperlukan.

\section{KEANDALAN SISTEM DISTRIBUSI $20 \mathrm{KV}$}

\section{A. Kestabilan Sistem Tenaga}

Kestabilan sistem tenaga listrik secara luas dapat didefinisikan sebagai kemampuan dari satu sistem tenaga listrik untuk tetap berada dalam kondisi seimbang dalam operasi normal dan dapat memperoleh kembali kondisi seimbang setelah sistem mengalami gangguan.

Berdasarkan Paper IEEE definition and classification of power system stability, kestabilan sistem tenaga listrik dibagi menjadi tiga kategori yaitu [2]:

1. Kestabilan sudut rotor [1]

Kestabilan sudut rotor adalah kemampuan dari beberapa mesin sinkron yang saling terinterkoneksi pada suatu sistem tenaga untuk mempertahankan kondisi sinkron.

2. Kestabilan frekuensi [2]

Kestabilan ini berkaitan dengan kemampuan dari sistem untuk mempertahankan kestabilan frekuensi akibat gangguan pada sistem yang mengakibatkan ketidakseimbangan antara pembangkitan dan beban.

3. Kestabilan tegangan [2]

Kestabilan tegangan dapat diartikan sebagai kemampuan dari sistem tenaga listrik untuk mempertahankan kestabilan nilai tegangannnya di semua bus pada sistem dalam kondisi operasi normal maupun setelah terjadi gangguan.

\section{B. Kestabilan Transien}

Kestabilan transien merupakan kemampuan dari sistem tenaga listrik untuk mempertahankan kondisi sinkron ketika sistem mengalami gangguan transien [1]. 
Gangguan transien ini berupa gangguan besar yang terjadi pada sistem seperti gangguan hubung singkat, lepasnya pembangkit, motor starting serta penambahan beban secara tiba-tiba.

\section{Pelepasan Beban [3]}

Jika terjadi gangguan pada sistem yang menyebabkan besarnya suplai daya yang dihasilkan oleh pembangkit tidak mencukupi kebutuhan beban misalnya karena adanya pembangkit yang lepas (trip), maka untuk mencegah terjadinya ketidakstabilan sistem perlu dilakukan pelepasan beban (load shedding). Keadaan yang kritis pada sistem dapat dideteksi melalui frekuensi sistem yang menurun dengan cepat.

Pelepasan beban dapat dilakukan dengan dua cara yaitu :

1. Pelepasan beban secara manual

2. Pelepasan beban secara otomatis

\section{Sistem KeLISTRIKAN PT. SEMEN ACEH}

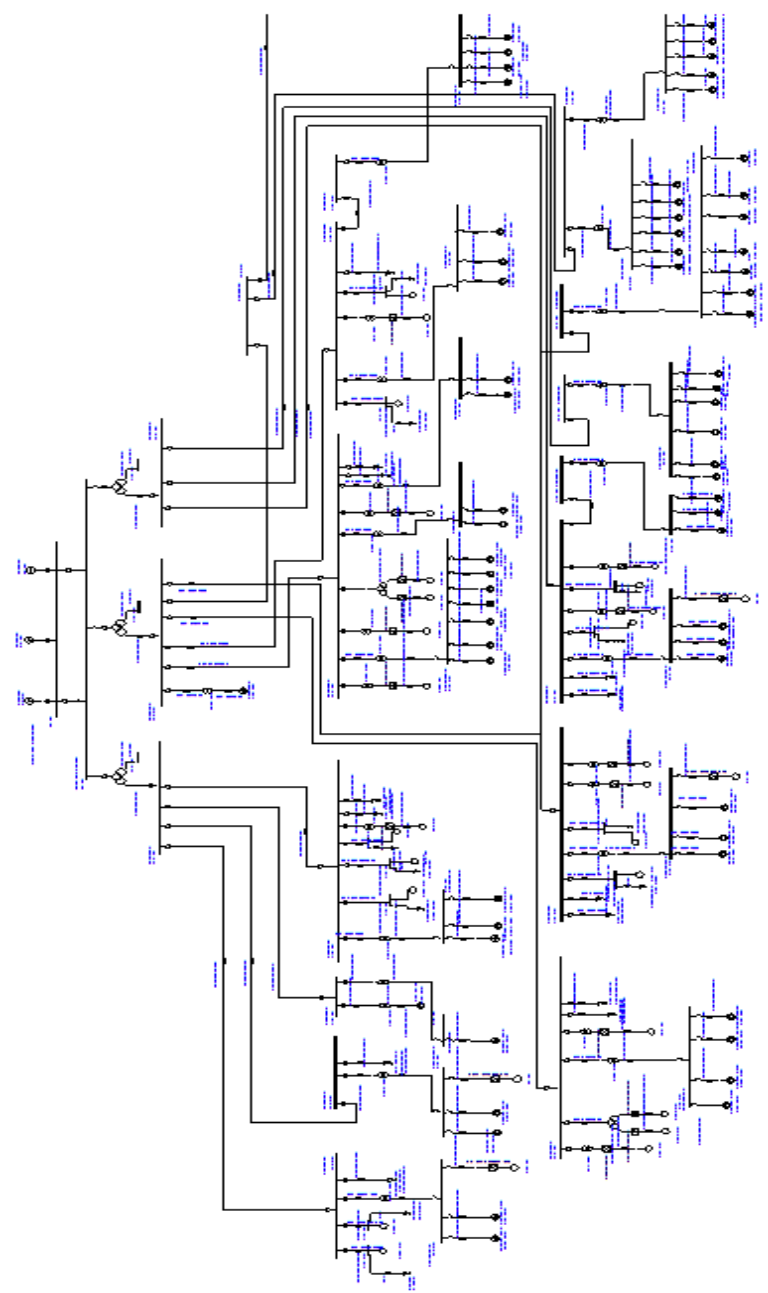

Gambar 1. Single Iine diagram alternatif 2 PT. Semen Aceh

Pada gambar 1. ditunjukkan single line diagram sistem kelistrikan alternatif 2 PT. Semen Indonesia Pabrik Aceh. Sedangkan single line diagram sistem kelistrikan alternatif 1 hanya berbeda dari sisi suplai generator pada alternatif 2 diganti dengan sumber PLN $150 \mathrm{kV}$ dan tegangan primer trafo 3 winding. Sistem kelistrikan PT. Semen Aceh terdiri dari beberapa level tegangan yaitu $150 \mathrm{kV}, 6.3 \mathrm{kV}$ dan $0.4 \mathrm{kV}$ untuk sistem kelistrikan alternatif 1 dan $11 \mathrm{kV}, 6.3 \mathrm{kV}$ dan $0.4 \mathrm{kV}$ untuk sistem kelistrikan alternatif 2. Sistem suplai terdiri dari 3 unit steam turbin generator dengan kapasitas masing - masing $30 \mathrm{MW}$ (841BG01) sebagai swing dan 2x25 MW sebagai voltage control pada sistem kelistrikan alternatif 2. Sedangkan pada sistem kelistrikan alternative 1, sistem suplai terhubung dengan grid PLN sebesar 3091 MVasc $150 \mathrm{kV}$. Total seluruh pembangkitan pada PT. Semen Aceh sebesar 42,38 MW dengan total beban sebesar 39, 39 MW.

\section{SIMULASI DAN ANALISIS TRANSIEN}

A. Studi kasus simulasi stabilitas transien

TABEL 1. KASUS DAN DESKRIPSI ANALISIS KESTABILAN TRANSIEN

\begin{tabular}{clc}
\hline \hline Kasus & \multicolumn{1}{c}{ Keterangan } & Waktu (s) \\
\hline Studi Kasus Alternatif 1 & \\
\hline \multirow{3}{*}{ SC 0.4 kV } & Hubung singkat 3 fasa pada bus 831LV08.1 & 2 \\
& 831LV08.1-CB1 open & 2.3 \\
& Hubung singkat 3 fasa pada bus 831LV08.2 & 2 \\
& 831LV08.2-CB1 open & 2.3 \\
& Hubung singkat 3 fasa pada bus 831MV08.1 & 2 \\
SC 6.3 kV & 831MV08.1-CB5 open & 2.3 \\
& Hubung singkat 3 fasa pada bus 831MV08.2 & 2 \\
& 831MV08.2-CB5 open & 2.3 \\
MS start & 341FN01M01 start & 2 \\
\hline Studi Kasus Alternatif 2 & 2 \\
\hline Gen Out & Generator 841BG02 trip & 2 \\
& Generator 841BG02 trip & 2.451 \\
Gen Out LS & Load shedding tahap 1 & 2.772 \\
& Load shedding tahap 2 & 2 \\
& Hubung singkat 3 fasa pada bus 831LV08.1 & 2.3 \\
SC 0.4 kV & 831LV08.1-CB1 open & 2 \\
& Hubung singkat 3 fasa pada bus 831LV08.2 & 2.3 \\
& 831LV08.2-CB1 open & 2 \\
& Hubung singkat 3 fasa pada bus 831MV08.1 & 2.3 \\
SC 6.3 kV & 831MV08.1-CB5 open & 2.3 \\
& Hubung singkat 3 fasa pada bus 831MV08.2 & 2 \\
& 831MV08.2-CB5 open & 2 \\
& 341FN01M01 start & \\
\hline \hline & &
\end{tabular}

B. Simulasi kasus generator outage

Pada subbab ini akan ditampilkan hasil simulasi untuk kasus generator outage.

1) Studi kasus Gen Out

TABEL 2. RESPON SUDUT ROTOR UNTUK KASUS GEN OUT

\begin{tabular}{ccc}
\hline \hline Gen ID & $\begin{array}{c}\text { Sudut rotor sebelum } \\
\text { gangguan }\end{array}$ & $\begin{array}{c}\text { Sudut rotor setelah } \\
\text { gangguan }\end{array}$ \\
\hline $841 \mathrm{BG} 02$ & Outage & Outage \\
$841 \mathrm{BG} 03$ & $21.77^{\circ}$ & $26.64^{\circ}$ \\
\hline \hline
\end{tabular}

TABEL 3. RESPON FREKUENSI UNTUK KASUS GEN OUT \begin{tabular}{cc}
\hline $\begin{array}{c}\text { Frekuensi sebelum gangguan } \\
(\%)\end{array}$ & $\begin{array}{c}\text { Frekuensi setelah gangguan } \\
(\%)\end{array}$
\end{tabular}

$100 \quad$ Tidak stabil

TABel 4. ResPON TEGANGAN UNTUK KASUS GEN OUT

\begin{tabular}{ccc}
\hline \hline Bus & $\begin{array}{c}\text { Tegangan sebelum } \\
\text { gangguan }(\%)\end{array}$ & $\begin{array}{c}\text { Tegangan setelah } \\
\text { gangguan }(\boldsymbol{\%})\end{array}$ \\
\hline Main Bus Sistem & 99.9997 & Tidak stabil \\
831MV012 & 99.7742 & Tidak stabil \\
831LV052 & 96.8178 & Tidak stabil \\
\hline
\end{tabular}

Dari data di atas dapat disimpulkan bahwa sistem tidak stabil dan harus dilakukan mekanisme pelepasan beban untuk mempertahankan kestabilan sistem. 


\section{2) Studi kasus Gen Out LS}

Pada kasus ini disimulasikan lepasnya generator 841BG02 dari sistem dan dilanjutkan dengan mekanisme load shedding. Mekanisme load shedding yang digunakan berdasarkan pada standar ANSI/IEEE C37.106-1987.

\section{Frekuensi}

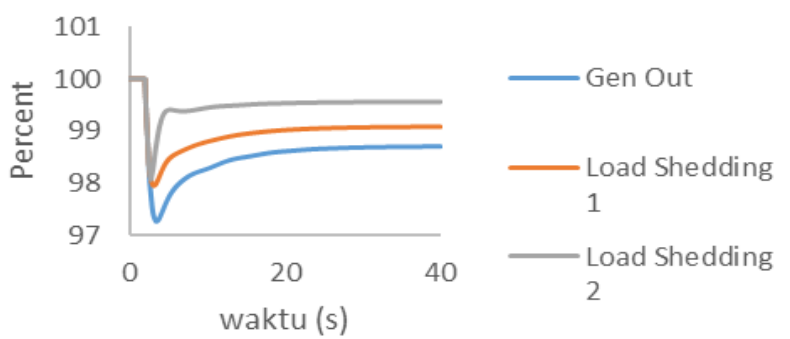

Gambar 2. Respon frekuensi sistem saat generator 841BG02 lepas dari sistem dan dilanjutkan dengan load shedding 2 tahap

Pada gambar 2. dapat dianalisis bahwa :

a. Garis biru (sebelum load shedding)

Frekuensi sistem turun secara signifikan hingga pada detik ke 30 menjadi $98.7 \%$ sehingga diperlukan load shedding untuk mengembalikan kestabilan sistem.

b. Garis orange (load shedding tahap 1)

Load shedding tahap 1 dilakukan saat frekuensi sistem turun mencapai 98.83\% Maka load shedding tahap 1 dilakukan saat 2.451 detik dengan melepas $10 \%$ total beban (4.24 MW).

c. Garis abu (load shedding tahap 2)

Load shedding tahap 2 dilakukan saat frekuensi sistem turun mencapai $98.16 \%$. Maka load shedding tahap 2 dilakukan saat 2.772 detik dengan melepas $15 \%$ total beban 9.97 MW). Setelah dilakukan load shedding tahap 2 frekuensi stabil di $99.56 \%$ atau $49.78 \mathrm{~Hz}$.

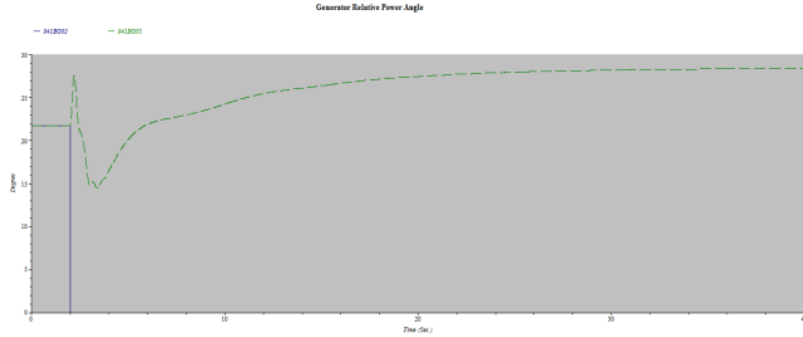

Gambar 3. Respon sudut rotor sistem saat generator 841BG02 lepas dari sistem dan dilanjutkan dengan load shedding 2 tahap

Pada gambar 3. dapat dilihat respon sudut rotor generator 841BG02 dan 841BG03. Sudut rotor generator $841 \mathrm{BG} 02$ saat sebelum gangguan $21.77^{\circ}$ dan berubah menjadi $0^{\circ}$. Pada sudut rotor $841 \mathrm{BG} 03$ saat sebelum gangguan $21,77^{\circ}$ dan berubah menjadi $28.41^{\circ}$.

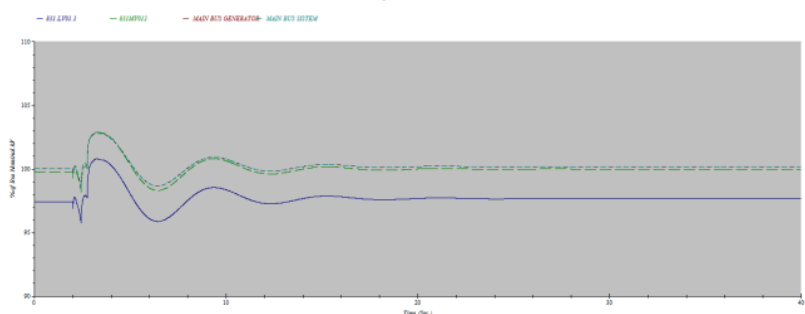

Gambar 4. Respon tegangan sistem saat generator 841BG02 lepas dari sistem dan dilanjutkan dengan load shedding 2 tahap

Pada gambar 4. dapat dilihat respon tegangan pada berbagai level tegangan. Sebelum gangguan tegangan berada pada $96,8182 \%$ dan level terendah didapatkan turun hingga $88,478 \%$ sedangkan untuk level tertinggi didapatkan $100,478^{\circ}$. Setelah dilakukan load shedding tahap 2 maka pada level setiap tegangan bus akan stabil pada 100,189\%. Dari hasil analisis di atas dapat disimpulkan bahwa tegangan sistem masih dalam batas standar PLN (+5\% dan -10\%) sehingga tegangan sistem dapat dikatakan stabil.

Dari hasil analisis respon sudut rotor, frekuensi dan tegangan sistem dapat disimpulkan sistem dapat kembali stabil untuk kasus generator 841BG02 lepas dari sistem setelah dilakukan load shedding tahap ke 2. Kuantitas beban yang harus dilepas adalah 9.97 MW atau $23.51 \%$ dari total beban.

\section{Simulasi kasus short circuit}

Pada subbab ini akan ditampilkan hasil simulasi untuk kasus Short Circuit.

1) Simulasi kasus SC $0.4 \mathrm{kV}$ (831LV081) alternatif 1

TABEL 9. RESPON FREKUENSI UNTUK KASUS SC $0.70 \mathrm{KV}$

\begin{tabular}{|c|c|c|c|}
\hline $\begin{array}{c}\text { Frekuensi } \\
\text { sebelum SC (\%) }\end{array}$ & \multicolumn{2}{|c|}{$\begin{array}{c}\text { Frekuensi maksimum } \\
\text { saat SC }(\%)\end{array}$} & $\begin{array}{c}\text { Frekuensi steasy } \\
\text { State }(\%)\end{array}$ \\
\hline 100 & 100 & & 100 \\
\hline \multicolumn{4}{|c|}{ TABEL 10. RESPON TEGANGAN UNTUK KASUS SC $70 \mathrm{KV}$} \\
\hline Bus & $\begin{array}{c}\text { Tegangan } \\
\text { sebelum } \\
\text { gangguan }(\%)\end{array}$ & $\begin{array}{c}\text { Tegangan } \\
\text { minimum } \\
\text { saat SC }(\%)\end{array}$ & $\begin{array}{c}\text { Tegangan } \\
\text { steady } \\
\text { state }(\%) \\
\end{array}$ \\
\hline Main Bus Sistem & 98.9403 & 99.3498 & 100.046 \\
\hline 831MV012 & 97.6492 & 99.0762 & 99.8414 \\
\hline 831LV052 & 99.6814 & 95.9175 & 96.8819 \\
\hline
\end{tabular}

Dari data di atas dapat disimpulkan bahwa sistem masih aman karena frekuensi dan tegangan masih dalam kondisi aman

2) Simulasi kasus SC $6.3 \mathrm{kV}(831 \mathrm{MV081})$ alternatif 1

TABEL 12. RESPON FREKUENSI UNTUK KASUS SC $22 \mathrm{KV}$

\begin{tabular}{cccc}
\hline \hline $\begin{array}{c}\text { Frekuensi } \\
\text { sebelum SC (\%) }\end{array}$ & $\begin{array}{c}\text { Frekuensi maksimum } \\
\text { saat SC }(\boldsymbol{\%})\end{array}$ & $\begin{array}{c}\text { Frekuensi steasy } \\
\text { State }(\boldsymbol{\%})\end{array}$ \\
\hline 100 & \multicolumn{2}{c}{100} & 100 \\
\hline \hline TABEL 13. RESPON TEGANGAN UNTUK KASUS SC 22 KV \\
Bus & $\begin{array}{c}\text { Tegangan } \\
\text { sebelum } \\
\text { gangguan (\%) }\end{array}$ & $\begin{array}{c}\text { Tegangan } \\
\text { minimum saat }\end{array}$ & $\begin{array}{c}\text { Tegangan } \\
\text { steady state } \\
(\boldsymbol{\%})\end{array}$ \\
\hline Main Bus Sistem & 99.9999 & 94.7189 & 100.056 \\
831MV012 & 99.7907 & 93.9664 & 99.852 \\
831LV052 & 96.8185 & 89.3593 & 96.895 \\
\hline \hline
\end{tabular}

Dari data di atas dapat disimpulkan bahwa sistem masih aman karena frekuensi, tegangan, dan sudut rotor generator masih dalam kondisi aman.

3) Studi kasus SC $0.4 \mathrm{kV}(831 \mathrm{LV081)}$ alternatif 2

TABEL 8. RESPON SUDUT ROTOR UNTUK KASUS SC $70 \mathrm{KV}$

\begin{tabular}{ccc}
\hline \hline Gen ID & $\begin{array}{c}\text { Sudut rotor sebelum } \\
\text { gangguan }\end{array}$ & $\begin{array}{c}\text { Sudut rotor setelah } \\
\text { gangguan }\end{array}$ \\
\hline $841 \mathrm{BG} 02$ & $21.77 \mathrm{o}$ & $21.78 \mathrm{o}$ \\
$841 \mathrm{BG} 03$ & $21.77 \mathrm{o}$ & $21.78 \mathrm{o}$ \\
\hline \hline
\end{tabular}

TABEL 9. RESPON FREKUENSI UNTUK KASUS SC $0.70 \mathrm{KV}$

\begin{tabular}{cccc}
\hline $\begin{array}{c}\text { Frekuensi } \\
\text { sebelum SC (\%) }\end{array}$ & $\begin{array}{c}\text { Frekuensi maksimum } \\
\text { saat SC }(\%)\end{array}$ & $\begin{array}{c}\text { Frekuensi steasy } \\
\text { State (\%) }\end{array}$ \\
\hline \hline \multicolumn{2}{c}{100.183} & 100.064 \\
\hline \hline TABEL 10. RESPON TEGANGAN UNTUK KASUS SC 70 KV \\
Bus & $\begin{array}{c}\text { Tegangan } \\
\text { sebelum } \\
\text { gangguan (\%) }\end{array}$ & $\begin{array}{c}\text { Tegangan } \\
\text { minimum saat } \\
\text { SC (\%) }\end{array}$ & $\begin{array}{c}\text { Tegangan } \\
\text { steady state } \\
(\boldsymbol{\%})\end{array}$ \\
\hline Main Bus Sistem & 99.9997 & 93.4757 & 100.063
\end{tabular}




$\begin{array}{llll}\text { 831MV012 } & 99.7742 & 92.6149 & 99.843 \\ \text { 831LV052 } & 96.8182 & 87.5541 & 96.905\end{array}$

Dari data di atas dapat disimpulkan bahwa sistem masih aman karena frekuensi, tegangan, dan sudut rotor generator masih dalam kondisi aman.

4) Studi kasus SC $6.3 \mathrm{kV}(831 \mathrm{MV081)}$ alternatif 2

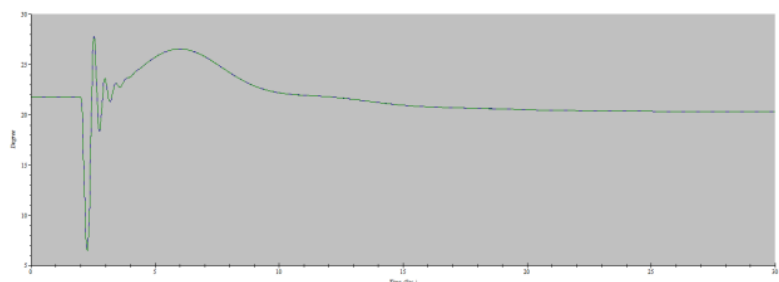

Gambar 5. Respon sudut rotor sistem saat generator 841BG02 lepas dari sistem dan dilanjutkan dengan load shedding 2 tahap

Pada gambar 5 dapat dilihat respon sudut rotor generator 841BG02 dan 841BG03. Sudut rotor generator $841 \mathrm{BG} 02$ saat sebelum gangguan $21.77^{\circ}$ dan berosilasi hingga mencapai nilai puncak $27,66^{\circ}$. Nilai steady state rotor generator $841 \mathrm{BG} 02$ dan $841 \mathrm{BG} 03$ menjadi $20,23^{\circ}$ setelah gangguan.

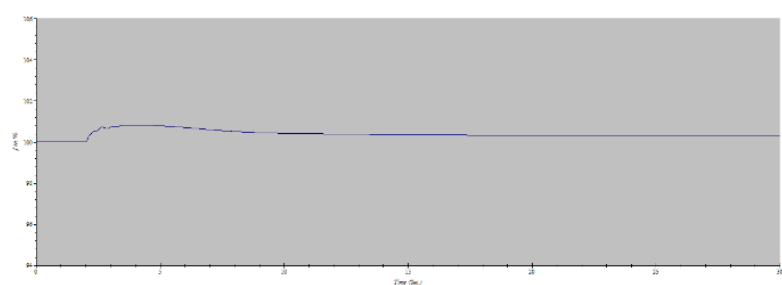

Gambar 6. Respon frekuensi saat terjadi gangguan hubung singkat 3 fasa pada bus 831MV081 dan CB5-831MV081 open mengatasi gangguan

Pada gambar 6. dapat dilihat respon frekuensi sistem saat mengalami gangguan hubung singkat pada bus 831MV081. Saat terjadi gangguan hubung singkat 3 fasa pada bus $831 \mathrm{MV} 081$ pada detik ke 2, frekuensi sistem naik mencapai $100.986 \%$. Hal ini diakibatkan karena membukanya CB5-831MV081 mengakibatkan hilangnya beban yang berada di bawah bus 831MV081 sehingga besarnya daya pembangkitan lebih besar dari daya yang dibutuhkan beban. Frekuensi mencapai kondisi steady state pada 100,38\%. Berdasarkan standar ANSI/IEEE C37.106-1987 dimana untuk operasi kontinu frekuensi dikatakan stabil jika nilainya antara 99.17-100.83\%, maka frekuensi sistem sudah stabil.

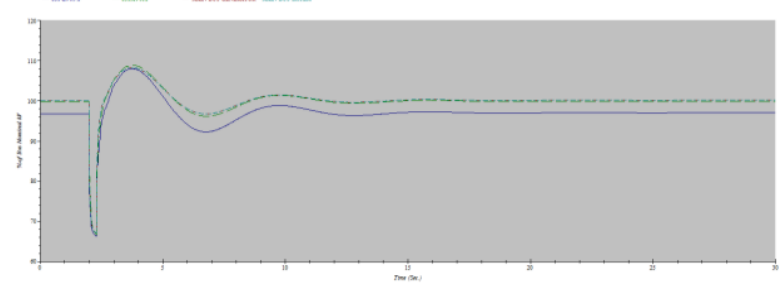

Gambar 7. Respon tegangan saat terjadi gangguan hubung singkat 3 fasa pada bus 831MV081 dan CB5-831MV081 open mengatasi gangguan

Pada gambar 7. dapat dilihat respon tegangan pada berbagai level tegangan. Nilai sebelum gangguan adalah $96,817 \%$. Setelah terjadi hubung singkat 3 fasa pada bus 831MV081 maka didapatkan nilai terendah dicapai pada $62,326 \%$ dan nilai tertinggi dicapai pada nilai $108,359 \%$. Kemudian sistem akan kembali stabil pada nilai $97,09 \%$ sehingga berdasarkan batas standar PLN (+5\% dan $10 \%$ ) hasil analisis di atas dapat disimpulkan bahwa tegangan sistem masih dapat dikatakan stabil. Dari hasil analisis respon sudut rotor, frekuensi dan tegangan sistem dapat disimpulkan sistem dapat kembali stabil untuk kasus hubung singkat pada bus 831MV081.

\section{Simulasi kasus motor starting}

Pada subbab ini akan ditampilkan hasil simulasi untuk kasus motor starting.

1) Simulasi kasus $M$ start alternatif 1

TABEL 11. RESPON FREKUENSI UNTUK KASUS MSTART

\begin{tabular}{ccc}
\hline \hline $\begin{array}{c}\text { Frekuensi sebelum } \\
\text { motor starting (\%) }\end{array}$ & $\begin{array}{c}\text { Frekuensi minimum } \\
\text { saat motor starting (\%) }\end{array}$ & $\begin{array}{c}\text { Frekuensi } \\
\text { steasy State (\%) }\end{array}$ \\
\hline \hline 100 & 99.83 & 99.8297 \\
\hline \hline
\end{tabular}

Gambar 8. Respon tegangan saat motor M532FN11 starting

Pada gambar 8. dapat dilihat respon tegangan pada saat motor 341FN01M01 starting. Pada bus 341FN01M01 nilai tegangan sebelum adanya motor starting 101,93\%. Namun setelah terjadi motor starting pada detik ke 2 tegangan akan turun sampai $72,20 \%$ kemudian akan kembali steady state pada nlai $91,57 \%$. Dari hasil analisis di atas dapat disimpulkan bahwa tegangan sistem masih dalam batas standar PLN (+5\% dan $-10 \%$ ) sehingga tegangan sistem dapat dikatakan stabil. Dari hasil analisis respon sudut rotor, frekuensi dan tegangan sistem dapat disimpulkan sistem dapat kembali stabil untuk kasus motor starting.

Dari hasil analisis respon frekuensi dan tegangan sistem dapat disimpulkan sistem dapat kembali stabil untuk kasus motor starting.

\section{2) Simulasi kasus $M$ start alternatif 2}

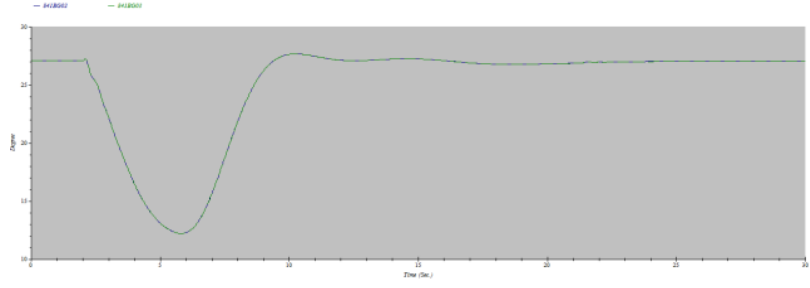

Gambar 9. Respon sudut rotor sistem saat motor 341FN01M01 start

Pada gambar 9. dapat dilihat respon sudut rotor generator 841BG02 dan 841BG03. Sudut rotor 841BG02 dan $841 \mathrm{BG} 03$ saat sebelum gangguan $27,09^{\circ}$, saat terjadi gangguan turun hingga $12,22^{\circ}$ dan mencapai kondisi steady state pada $27,09^{\circ}$

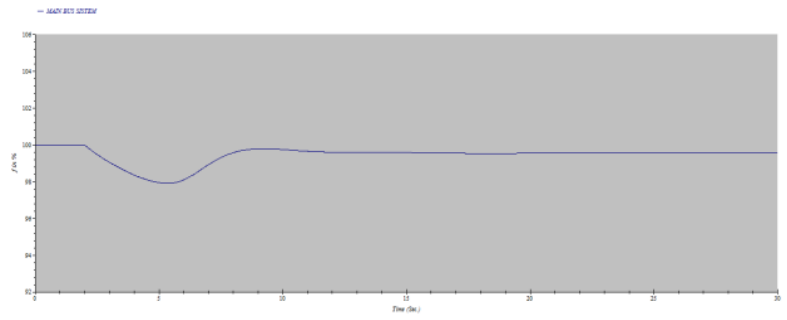

Gambar 10. Respon frekuensi saat motor 341FN01M01 start

Pada gambar 10. dapat dilihat respon frekuensi sistem saat motor 341FN01M01 starting. Saat motor 341FN01M01 starting pada detik ke 2, frekuensi sistem turun mencapai $97,913 \%$. Hal ini dikarenakan pada saat 
motor starting, motor menyerap daya yang sangat besar dalam beberapa detik. Frekuensi mencapai kondisi steady state pada 99,567\%. Berdasarkan standar ANSI/IEEE C37.106-1987 dimana untuk operasi kontinu frekuensi dikatakan stabil jika nilainya antara 99.17-100.83\%, maka frekuensi sistem sudah stabil.

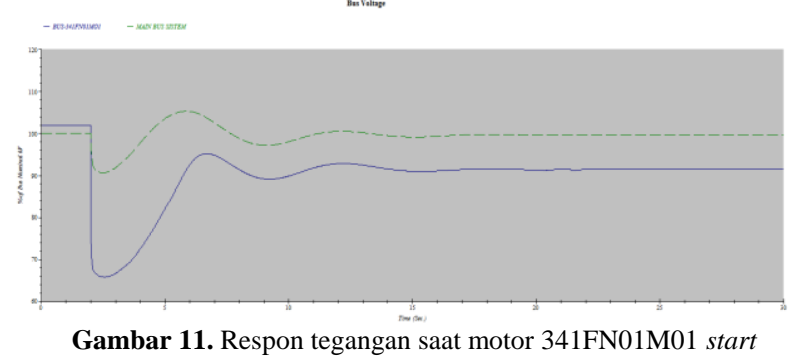

Pada gambar 11. dapat dilihat respon tegangan pada saat motor 341FN01M01 starting. Pada bus 341FN01M01 nilai tegangan sebelum adanya motor starting $101,89 \%$. Namun setelah terjadi motor starting pada detik ke 2 tegangan akan turun sampai 65,79\% kemudian akan kembali steady state pada nlai 91,456\%. Dari hasil analisis di atas dapat disimpulkan bahwa tegangan sistem masih dalam batas standar PLN (+5\% dan $-10 \%$ ) sehingga tegangan sistem dapat dikatakan stabil. Dari hasil analisis respon frekuensi dan tegangan sistem dapat disimpulkan sistem dapat kembali stabil untuk kasus motor starting.

\section{KESIMPULAN/RINGKASAN}

1. Pada kasus lepasnya generator mengakibatkan sistem menjadi tidak stabil. Untuk mengembalikan kestabilan sistem akibat lepasnya satu generator (841BG02) memerlukan pelepasan beban 2 tahap.

2. Pada kasus hubung singkat sistem kelistrikan Alternatif 1 di level tegangan 6,3kV (831MV081), sistem tetap dalam keadaan stabil.

3. Pada kasus hubung singkat sistem kelistrikan Alternatif 1 di level tegangan 0,4kV (831LV081), sistem tetap dalam keadaan stabil.

4. Pada kasus hubung singkat sistem kelistrikan Alternatif 2 dilevel tegangan $0,4 \mathrm{kV}$, setiap level tegangan nilai akan turun setelah terjadi gangguan hubung singkat 3 fasa pada level tegangan $0,4 \mathrm{kV}$, namun setelah CB1-831LV081 open maka nilai tegangan sesaat menjadi 99,513\% dan akan kembali steady state pada $96,905 \%$.
5. Pada kasus hubung singkat sistem kelistrikan Alternatif 2 dilevel tegangan $6,3 \mathrm{kV}$, setiap level tegangan nilai akan turun setelah terjadi gangguan hubung singkat 3 fasa pada level tegangan $6,3 \mathrm{kV}$, namun setelah CB5-831MV081 open maka nilai tegangan sesaat menjadi 108,359\% dan akan kembali steady state pada $97,09 \%$.

6. Pada kasus motor starting, pada sistem kelistrikan Alternatif 1 penurunan tegangan terendah sempat pada $72,20 \%$ dan sistem kembali stabil pada $91,57 \%$ serta pada Alternatif 2 penurunan tegangan terendah sempat pada $65,79 \%$ dan sistem kembali stabil pada $91,456 \%$.

\section{DAFTAR PUSTAKA}

[1] Kundur, Prabha, "Power System Stability and Control”, McGrawHill Companies Inc, 1994.

[2] IEEE/CIGRE Joint Task Force on Stability Terms and Definitions, "Definition and Classification of Power System Stability”, IEEE Transactions on Power System, Vol. 19, No. 2, May 2004.

[3] Marsudi, Djiteng, “Operasi Sistem Tenaga Listrik”, Yogyakarta: Graha Ilmu, 2006.

\section{BIOGRAFI}

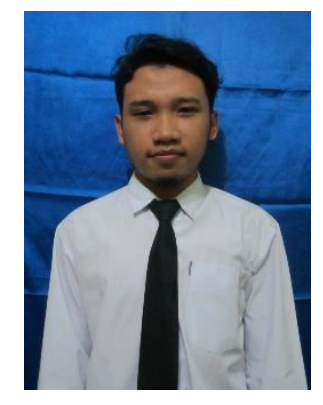

David Firdaus, dilahirkan di Probolinggo, 21 September 1992. Anak kedua dari 3 bersaudara. Pendidikan berawal dari TK Taruna Dra. Zulaeha pada tahun 1997-1999. Kemudian melanjutkan ke SD Taruna Dra.Zulaeha pada tahun 1999 2005. Setelah itu ia melanjutkan pendidikannya ke SMP Taruna Dra. Zulaeha pada tahun 2005 - 2008, setelah lulus ia diterima sebagai murid SMA Taruna Dra. Zulaeha pada tahun 2008 - 2011. Pada tahun yang sama ia masuk ke Jurusan D3 Teknik Elektro Industri - PENS hingga lulus tahun 2014. Kemudian ia melanjutkan studi Program Sarjana di Institut Teknologi Sepuluh Nopember Surabaya lewat program Lintas Jalur dan mengambil bidang studi Teknik Sistem Tenaga. 